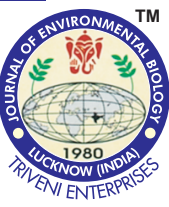

\title{
Assessment of Leuconostoc spp. invasion in standing sugarcane with cracks internode
}

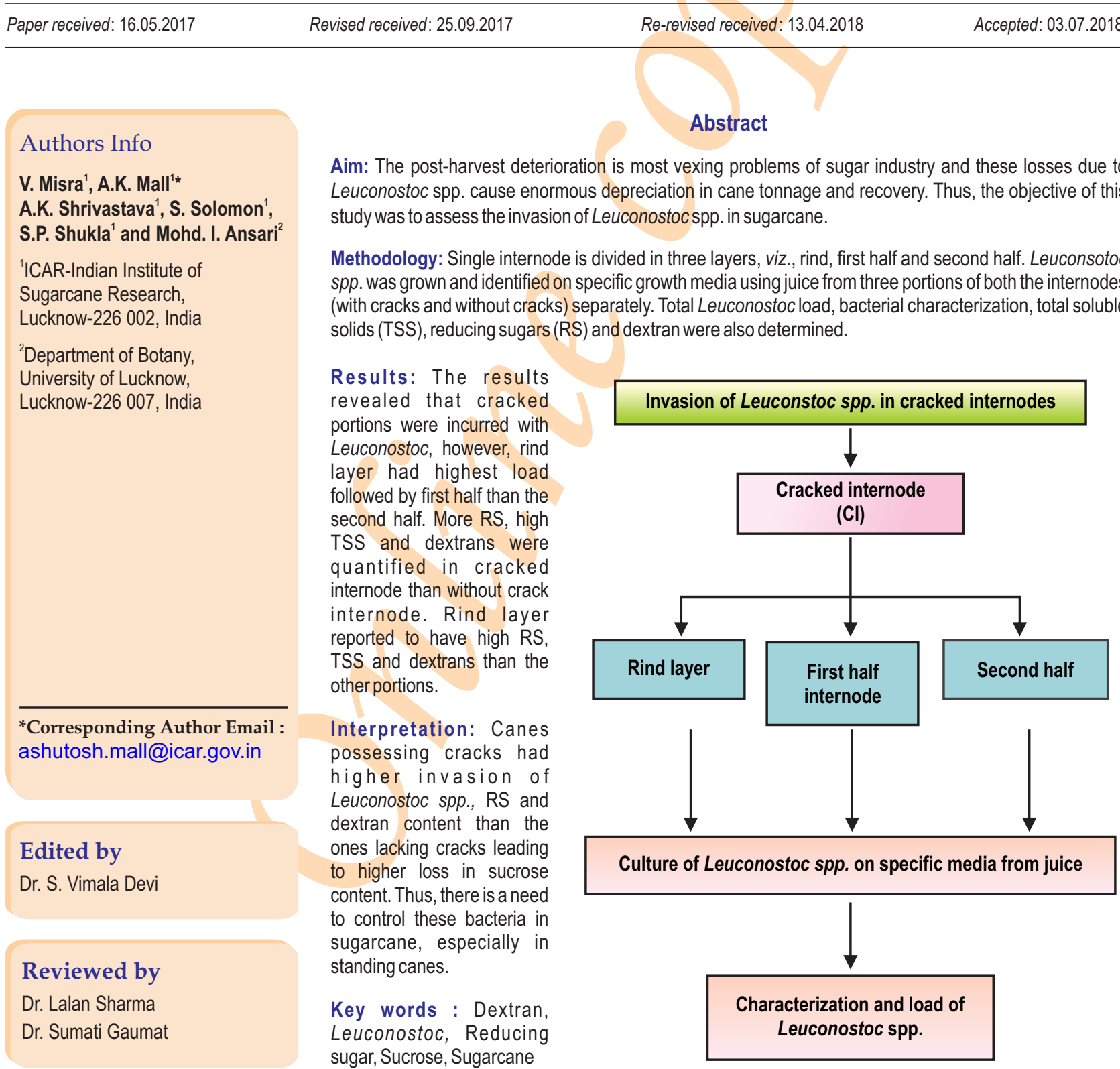

How to cite : Misra, V., A.K. Mall, A.K. Shrivastava, S. Solomon, S.P. Shukla and Mohd. I. Ansari: Assessment of Leuconostoc spp. invasion in standing sugarcane with cracks internode. J. Environ. Biol., 40, 316-321 (2019). 


\section{Introduction}

Lucrative part in sugarcane commonly outstays with growth cracks and frequently occurs in any crop stage which depends not only on varieties but even on growing conditions. Exposure of canes to freezing is one of the common features for appearance of cracks on internodes (Eggleston et al., 2004), apart from excessive intake of water or nutrients by the crop. Sugarcane cracks may be deep in depth or up to the epidermis surface only (Philippe et al., 2000). These cracks allow increased water loss and expose to various biotic stresses (Sandhu et al., 2016). Exposure of cane internal rich regions due to occurrence of cracks is indeed a feast for invasion of microorganisms, especially bacteria like Leuconostoc spp., for which such conditions are favorable for growth and proliferation (Solomon, 2009; Misra et al., 2017). The invasion of microorganisms causes several problems which directly or indirectly affects the crop yield or its final product. One of the most vital and evergreen problem in sugarcane is deterioration of sucrose content in pre- and postharvest conditions. There are many factors behind it but pre- and post- exposure of sugarcane with microorganisms is crucial amongst all (Solomon, 2009; Misra et al., 2016). The former may be due to occurrence of these cracks on cane stalk while latter due to different harvesting methods applied on canes. Invasion of these microorganisms in cane stalks causes deterioration in sucrose content leading to poor quality of juice either in preand/or post- harvest condition (Solomon, 2000). It is well known that such canes are known as sour canes. It is obvious that microorganisms after harvest in sour cane proliferate at a higher rate, much higher than the stale canes. Management techniques in sugarcane has already been developed for controlling diseases, insects and pest's incidence, however, invasion of microorganisms can only be minimized, but not controlled. It is known that sucrose content in canes, possessing growth cracks, are poor and also such internodes cannot be used for planting because sett gets easily exposed to fungal and bacterial infection along with frequent incidence of insect and pests (Bakker, 1999). At times sugarcane possessing corky cracks is often misunderstood with growth cracks, however, they differ from the latter as former may be deep and run through the whole length of internode of sugarcane (Philippe et al., 2000).

Leuconostoc spp. is one of the most important soil borne bacteria and is mainly responsible for the sucrose loss occurring in pre- or post- harvested sugarcane, as these enters easily into damaged cane (Misra et al., 2015). Studies have reported that these bacteria are the sole reason behind the microbial deterioration of damaged sugarcane even though invasion of several other kinds of bacteria are also possible (Singh et al., 2015; Hector et al., 2015). Solomon (2000) and Misra et al. (2016) reported that in sour cane/stale canes, presence of these bacteria causes the sucrose content to deteriorate leading to formation of organic acids along with typical smell of sourness. This bacterium is responsible for the production of dextrans (Bukhari et al., 2015;
Faramarzi et al., 2013) and mannitol (Eggleston et al., 2004) in harvested canes, implying that a rapid deterioration in sucrose qualities lowers the sugar recovery (Hector et al., 2015). The formation of dextran not only deteriorates the sucrose content in cane stalks but creates several problems during milling in sugar factories such as increase in viscosity (affects the crystallization rate as rate of heat exchange gets lowered), alteration in sugar crystal shape, etc. (Solomon, 2000). In view of the above, the present study aimed to assess the invasion of Leuconostoc spp. from growth cracks in standing sugarcane.

\section{Materials and Methods}

Plant materials: The whole single canes cracked at internodes were selected for the study and crack internodes were separated from the stalk. Each cracked internode were cut longitudinally into three parts, viz., outer rind layer, layer next to rind layer and remaining portion, for assessment of invasion of the Leuconostoc spp. through these cracks (Fig. 1).

Microbial analyses: Juice was extracted from internodes possessing cracks as well as normal internodes. The latter, viz., normal internodes were considered as control. Juice was extracted with the help of a hand crusher so that the juice is free from extra microbial invasion as cleaning and sanitizing the hand crusher is easier. As already mentioned, the cracked internodes were separated so it would be difficult to extract juice in routine crushers. A $100 \mu$ l of extracted juice from cracked internode and normal internode were poured and spread in separate sterile plates containing specific media-tryptone $(10 \mathrm{~g})$, yeast extract (5 $\mathrm{g}$ ), sucrose $(100 \mathrm{~g})$, agar $(20 \mathrm{~g})$ for $1000 \mathrm{ml}$ of media (Mc-Cleskey et. al., 1947) for the growth of Leuconostoc spp., which were spread with the help of spreader and the plate was incubated at $30^{\circ} \mathrm{C}$ for $24-48 \mathrm{hrs}$ for good bacterial growth. The media was sterilized at $121^{\circ} \mathrm{C}$ for $15 \mathrm{~min}$ and prior using this media, $0.005 \%$ of sodium azide was added to prevent the growth of other bacteria. Total Leuconostoc spp. load was calculated manually.

Further, identification and characterization of Leuconostoc spp. colonies were performed as per the Bergey's Manual. As a preliminary test, separate isolated colonies from each plate were tested for Gram's staining and catalse test. Further confirmation of bacteria were performed by biochemical tests following Bergey's Manual (Holt, 2000). Colony characterizations were studied by observing the isolated colonies under magnifying glass (10X).

Biochemical analyses: Juice extracted from cracked internodes and normal internodes were collected separately in clean sterile beakers. Associated biochemical parameters (reducing sugars and dextran) with Leuconostoc spp. were also studied. Reducing sugars was estimated following the method of Nelson (1944); Dextran was estimated by the method of Haze (Keniry et al., 1969) whereas total soluble solids were determined by hand refractometer. 


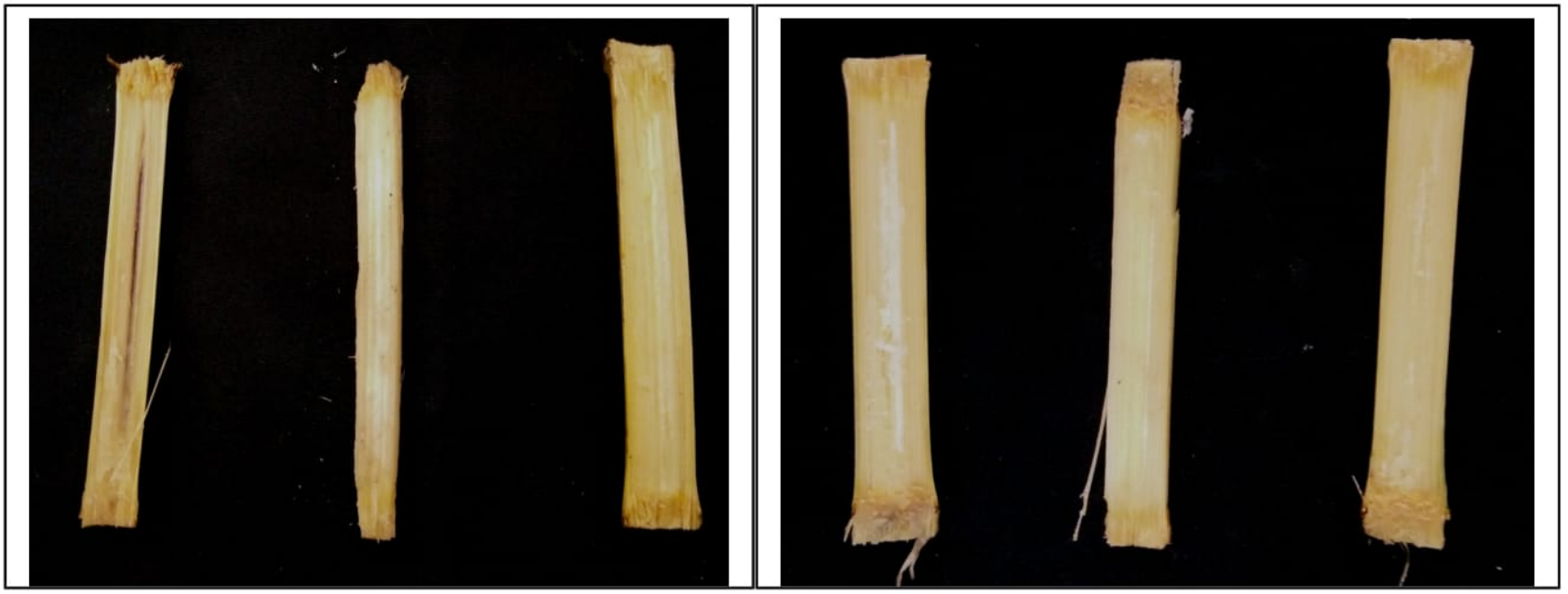

Fig. 1: Longitudinal section of (a) internode with crack (b) without crack.

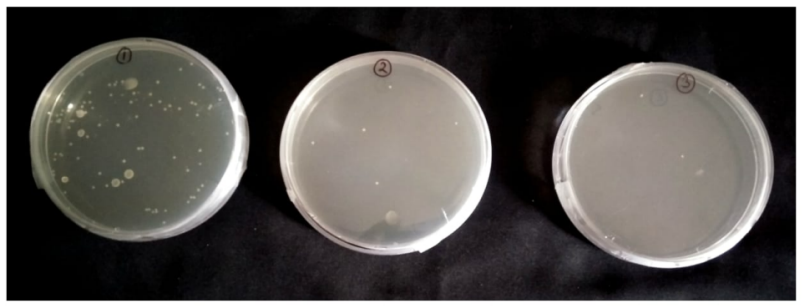

(a)

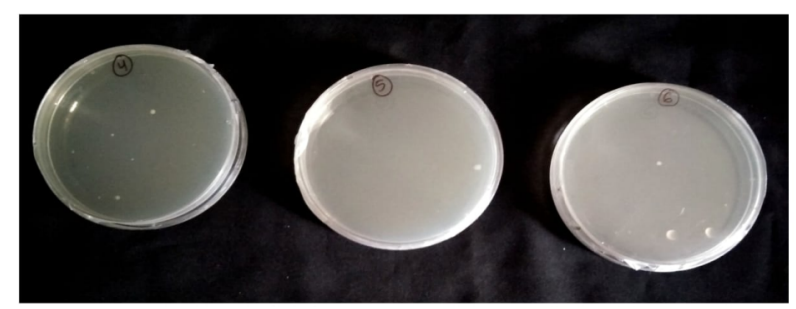

(b)

Fig. 2 : Leuconostoc load in (a) crack internode and (b) internode without crack in different parts of single internode (1,4-Rind layer; 2.5 Firsthalf; 3,6-Second half).

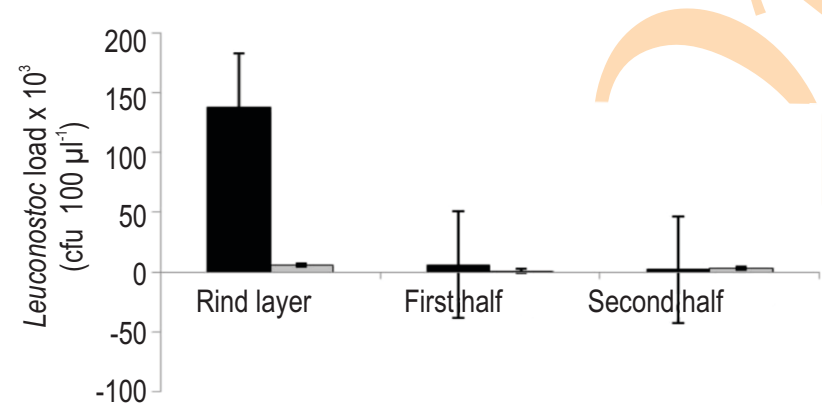

Fig. 3 : Leuconostoc spp. Load in $\mathrm{Cl}$ and $\mathrm{WCl}$ in different parts of single internode.
Statistical analyses : The data were analyzed by appropriate statistical analysis (Gomez and Gomez, 1984) using CropStat 7.2 (2009) programme. The second order statistics were computed following Singh and Chaudhury (1985).

\section{Results and Discussion}

The bacterial colonies were Gram positive and showed negative catalase test. Colony characteristics showed that the bacterial colonies were smooth, entire, oval in shape, convex, semi-transparent and mucous rich. Furthermore, biochemical analyses showed that the bacteria were able to ferment glucose, mellibiose, maltose, sucrose, fructose, dextrose and lactose, evolving oxygen gas, but lacked in fermenting starch, salicin, Dribose, raffinose and aesculin. The above biochemical tests confirmed that the bacterial colonies were Leuconostoc spp. as per Bergey's manual (Holt et al., 1994)

A high possibility of Leuconostoc bacteria invading through cracks and cut ends has been reported (Solomon, 2009). In cracked internode, of all the three portions, the outer rind layer had the highest Leuconostoc load $\left(138 \times 10^{3} \mathrm{cfu} 100 \mu^{-1}\right)$, followed by the first half $\left(6 \times 10^{3} \mathrm{cfu} 100 \mu \mathrm{l}^{-1}\right)$ and second half $\left(2 \times 10^{3}\right.$ cfu $\left.100 \mu^{-1}\right)$. There was a difference of 132 units between the rind layer and first half, while 136 units between rind layer and second half. The difference in Leuconostoc load clearly indicated that Leuconostoc invaded through the growth cracks appearing on the cane stalk, irrespective of the standing or harvested canes (Fig. 2). However, in the normal internodes, few number of Leuconostoc spp. were observed in all the portions (Fig. 3). The presence of Leuconostoc spp. in normal internode may be due to its invasion from soil when the setts were planted. This may be associated with the fact that the canes having more cracks in their stalk will have more probability of Leuconostoc spp. invasion, 


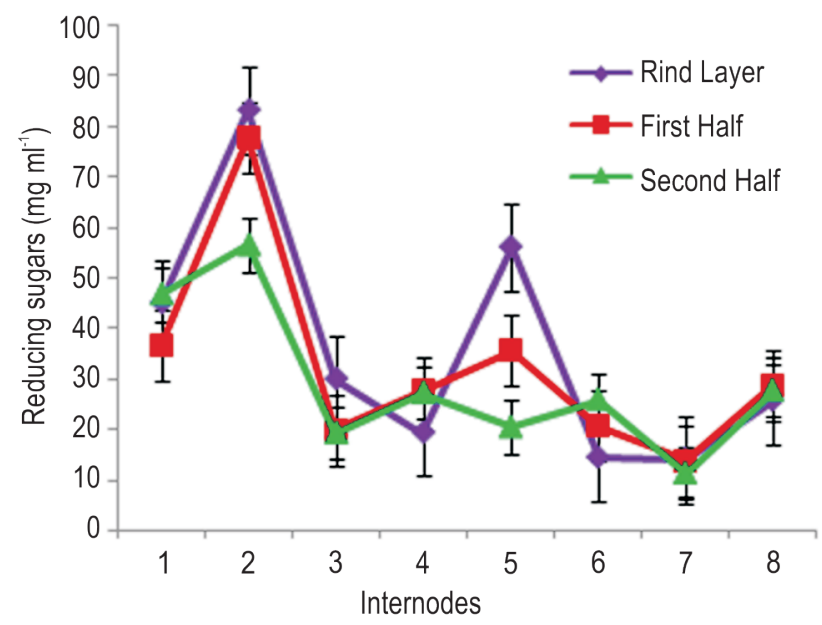

Fig. 4 : Reducing sugars in cracked internodes

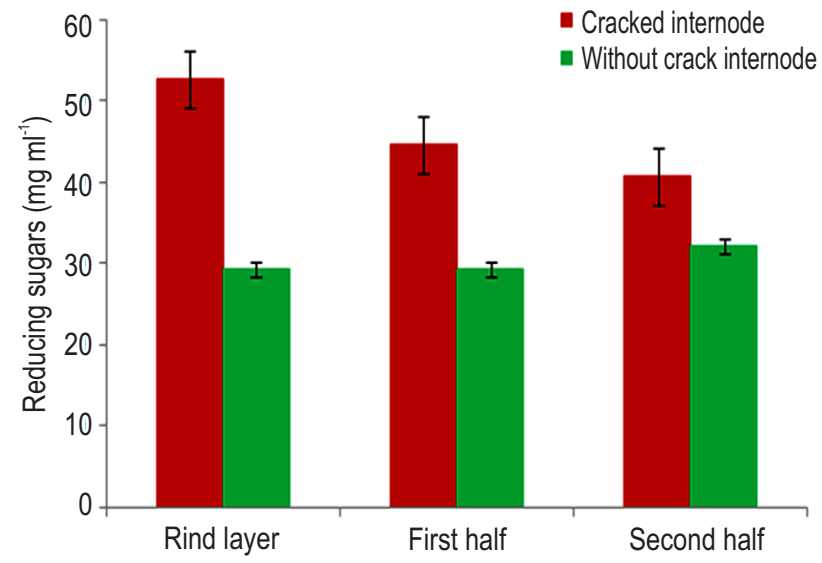

Fig. 6 : Reducing sugars ( $\mathrm{mg} \mathrm{ml}^{-1}$ ) in cracked and normal internode in different parts of single internode.

thus have higher probability of sucrose deterioration after harvest (Misra et al., 2016; 2017). Sharma and Chandra (2017) reported a new Leuconostoc spp. for post-harvest losses that mainly invade through cracks or through cut ends. Samina (2012) illustrated that there are multiple sites like growth cracks, globules rich in sucrose content, regions underneath sheath, etc., for invasion of microbes in the sugarcane. Studies have reported that microbial infection in canes is possible due to damage in cane stalks either by growth cracks on internodes or cut regions in the harvested canes (Solomon 2009; Misra et al., 2017; 2016). Invasion of Leuconsotoc spp. in stale cane juice has been reported by Singh etal. (2015).

In cracked internodes, of all the three portions, the rind layer (outer) had the highest reducing sugars (of $52.69 \mathrm{mg} \mathrm{ml}^{-1}$ ), followed by the first half (44.64 mg ml-1) and second half $(40.80 \mathrm{mg}$ $\mathrm{ml}^{-1}$ ). This may be due to more microbes, especially Leuconostoc spp. on the rind layer as they found favorable conditions for their

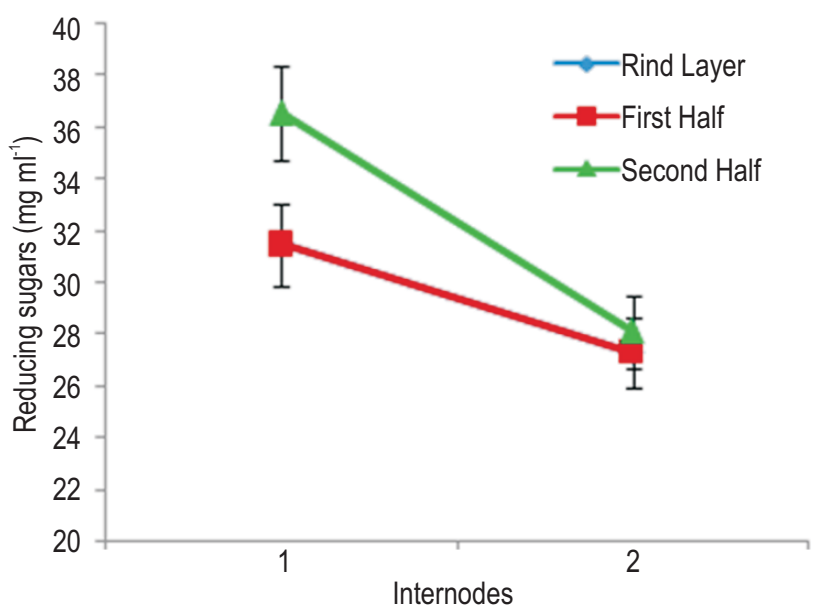

Fig. 5 : Reducing sugars in normal internodes.

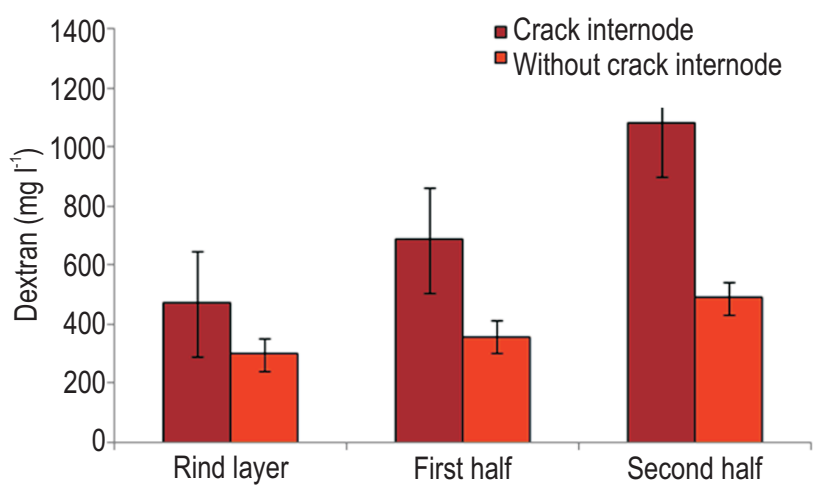

Fig. 7 : Dextran in cracked and normal internode in different parts of single internode.

growth and proliferation. However, in normal internodes, of all portions, the first and second half had approximately same reducing sugars $\left(29.35 \mathrm{mg} \mathrm{ml}^{-1}\right)$ with a slight increase in reducing sugars in the second half $\left(32.28 \mathrm{mg} \mathrm{ml}^{-1}\right)$. In different cracked internodes, the reducing sugars of same portion were significantly different $(C D=14.15)$ along with significant difference in different portions $(C D=20.01)$ (Fig. 4). There was even a significant difference in normal internodes of same portions $(C D=0.99)$, as well as among the different portions $(C D=1.40)$ (Fig. 5). On comparing the cracked internodes and normal internodes, reducing sugars were highest in cracked internodes by 23.34 units, 15.29 units and 8.52 units in rind layer, first half and second half, respectively (Fig. 6). The statistical analysis showed that the cracked internodes and normal internodes were significantly different $(C D=4.26 ; C V=6.144)$. This indicated that sucrose is converted more into glucose and fructose in case of cracked internodes. Studies have reported that there is an association between bacteria and sucrose deterioration (Suman 


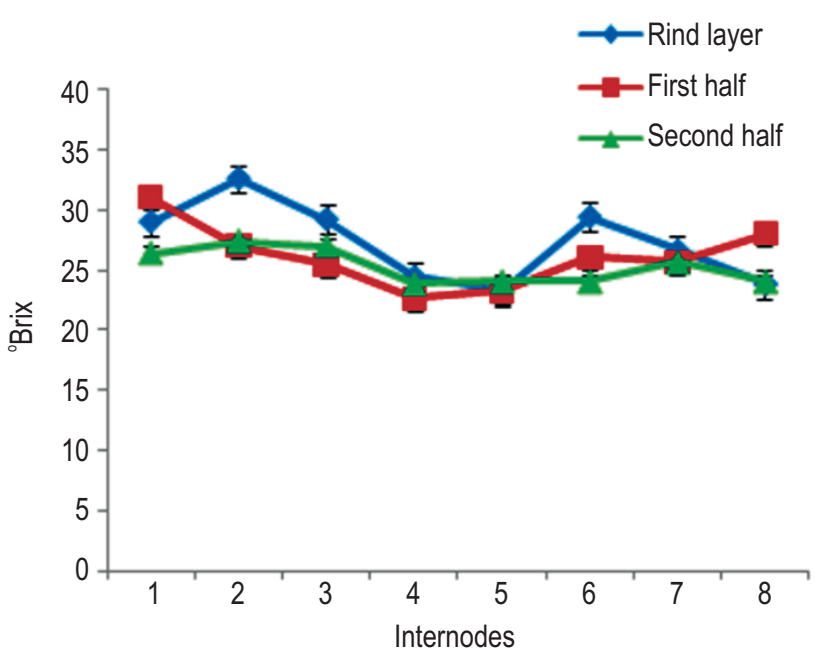

Fig. 8 : Total soluble solids in cracked internodes.

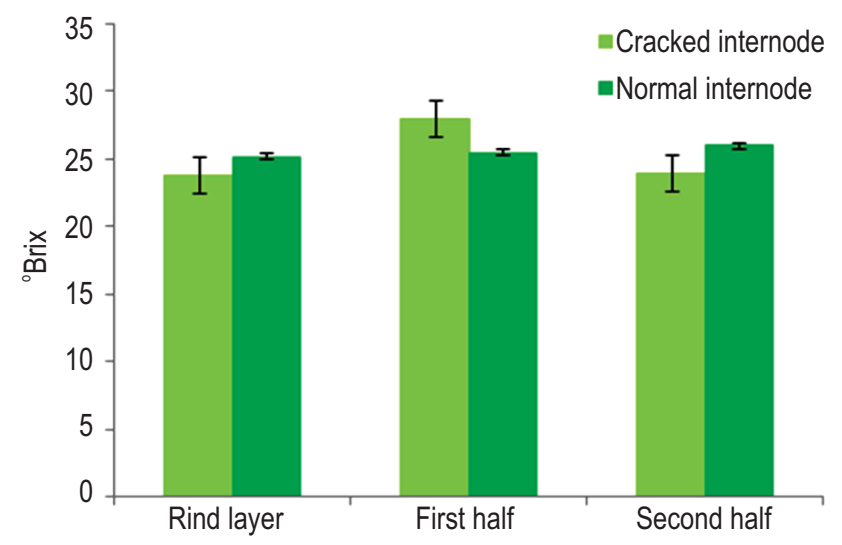

Fig. 10 : Total soluble solids in cracked internode and normal internode in different part of single internode.

et al., 2000) which is being clearly depicted from the results. Singh and Solomon (2003) had revealed that more the invasion sites for microbes, faster will be the loss of sucrose into reducing sugars dextran and related polysaccharides. This is also evidently illustrated in the results obtained that the internodes possessing cracks had higher reducing sugar than the normal ones.

Microbial invasion may be associated with the amount of dextran present. The formation of dextran takes place due to conversion of sucrose in the presence of dextrasucrase enzyme. This enzyme is associated with Leuconostoc spp. (Solomon, 2009; Misra et al., 2016). In cracked internodes, the rind layer $\left(470 \mathrm{mgl}^{-1}\right)$ had least amount of dextran followed by first half (688 $\mathrm{mg} \mathrm{l}^{-1}$ ) and second half $\left(1078 \mathrm{mgl}^{-1}\right)$ (Fig. 7). Even though there is higher microbial growth on the rind layer (favorable conditions for their growth and proliferation) but it may be possible that the

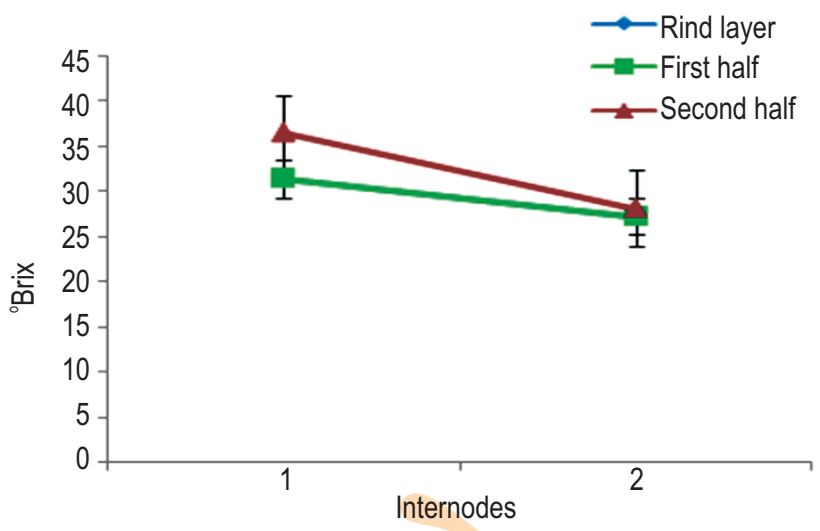

Fig. 9 : Total soluble solids in normal internodes.

formation of dextran could be low due to the less amount of sucrose present in the rind layer in comparison to the left-over portion. However, in normal internodes, all portions had almost similar pattern of dextran concentration (301, 359 and $489 \mathrm{mg} \mathrm{l}^{-1}$ in rind layer, first half and second half, respectively) as in cracked internodes but variation among the portions was less compared to cracked internodes. Although the presence of dextran in freshly harvested sugarcane was negligible, however, in this study there was presence of dextran in freshly harvested cracked as well as normal internodes. Furthermore, the dextran concentration in cracked internodes with respect to normal internodes showed that cracked internodes had higher dextran concentration in comparison to internodes free from cracks $(56.14,91.64,120.44$ $\%$ in rind, first half and second half, respectively). This variation in dextran concentration of cracked internodes and normal internodes were statistically significant $(C D=121.93 ; C V=11.88)$. This indicated that sucrose is converted more into dextran in cracked internodes. Formation of dextran in sugarcane stalks is a matter of concern for sugarcane millers as it is one of the factors responsible for sucrose deterioration (Eggleston et al., 2009; Solomon, 2009; Aquino and Franco, 2009). Several studies have reported that accumulation of dextran due to Leuconostoc mesenteroides (Hou et al., 2018; Katina et al., 2009) leads to increased sugarcane deterioration (Solomon, 2009; Eggleston and Monge, 2005; Eggleston et al., 2009; Aquino and Franco, 2009; Eggleston, 2002). It has been previously reported that production of $0.1 \%$ dextran leads to decrease of $0.04 \%$ sucrose (Solomon, 2000).

In different cracked internodes, there was significant difference in total soluble solids within the same portions $(C D=3.14)$ in different internodes as well as among the different portions $(C D=4.44)$ of same internode (Fig. 8). This was also true in case of normal internodes $(C D=0.99 ; 1.40$ in within and among different portions, respectively) (Fig. 9). A decreasing pattern of total soluble solids in the three portions in cracked internodes was observed while it was vice-versa in normal internodes (Fig. 10). In cracked internodes, the rind layer and second half had almost 
same total soluble solids ( 23.8 and 24 , respectively), but the first half possessed highest total soluble solids (28). In normal internodes, there was no significant difference in total soluble solids among the three portions and possessed almost same amount of total soluble solids in the three portions. Higher increase in total soluble solids was observed in cracked internodes in comparison to normal internodes. This variation was found to be statistically significant ( $C D=0.99$; $C V=3.03)$. Studies have shown rapid increase in total soluble solids after 240 hrs of harvest, irrespective of the type of cane such as damaged, drought or waterlogging affected, etc. (Misra et al., 2016a; Misra et al., 2016b).

Invasion of microbes through cut/damaged parts is a factor for losses in cane weight and sugar recovery. Leuconostoc bacterium invades through the rind of cracks into the stalk interior thus revealing higher probability of faster rate of sucrose deterioration after these canes are harvested.

\section{Acknowledgment}

Authors wish to thank the Director, ICAR-Indian Institute of Sugarcane Research, Lucknow for the encouragement and the facilities extended for this work.

\section{References}

Aquino, F.W.B. and D.W. Franco: Molecular mass distribution of dextran in Brazilian sugar and insoluble deposits of cachaça. Food. Chem. 114, 1391-95 (2009).

Bakker, $H_{\text {.: }}$ Sugar cane cultivation and management. Springer Publication, p. 642 (1999).

Bukhari, M., S.E. Khaseh, A. Osman and S. Eldeen F.: Investigations of the influence of dextran on sugar cane quality and sugar cane processing in Kenana sugar factory. Hegazi J. Chem. Pharm. Res., 7, 381-392 (2015).

Eggleston, G. and A. Monge: Optimization of sugarcane factory application of commercial dextranases. Process Biochem., 40 1881-1894 (2005).

Eggleston, G., A. Monge, B. Montes and D. Stewart: Application of dextranases in sugarcane factory: Overcoming practical problems. Sugar Tech, 11, 135-141 (2009).

Eggleston, G., B. Legendre and T. Tew: Indicators of freeze-damaged sugarcane varieties, which can predict processing problems. Food Chem., 87, 119-133 (2004).

Eggleston, G.: Deterioration of cane juice-sources and indicators. Food Chem.78, 95-103 (2002).

Faramarzi, M., Y. Rahimi Kashkouli, H.R. Rahimi Kashkouli and D. Gholamzadeh: Production of dextran from sugar cane molasses by Leuconostoc mesenteroides. Armaghane Danesh, 18,184-193 (2013).

Gomez, K.A. and A.A. Gomez: Statistical Procedures for Agricultural Research. $2^{\text {nd }}$ Edn., John Wiley \& Sons. Inc., p. 680 (1984).

Hector, S., K. Willard, R. Bauer, I. Mulako, E. Slabbert, J. Kossmann and G. M. George: Diverse exopolysaccharide producing bacteria isolated from milled sugarcane: Implications for cane spoilage and sucrose yield. Plos One, 10, e0145487 (2015).
Holt, J.G.: Bergey's Manual of Determinative Bacteriology. $9^{\text {th }}$ Edn. Philadelphia: Lippincott Williams and Wilkins, pp. 529-541 (2000).

Hou, D. Z., Y.Y. Pu, Q.S. Zou, H.L. Chen, Y. Yu, S.X. Huang and S. Chen Improvement of dextransucrase activity by glucose acclimation cultivation and kinetics of sucrose consumption. Sugar Tech, 20 60-68 (2018).

Katina, K., N.H. Maina, R. Juvonen, L. Flander, L. Johansson, L. Virkki, M. Tenkanen and A. Laitila: In situ production and analysis of Weissella confusa dextran in wheat sourdough. Food Microbiol., 26, 734-43 (2009).

Keniry, J.S., J.B. Lee and V.C. Mahoney: Improvements in the dextran assay of sugar cane materials. Int. Sugar J., 71, 230 (1969).

Mc-Cleskey, C.S., L.W. Faville and Barnett: The application of bacteriophage and serology in the differentiation of strains of Leuconostoc mesentroides from cane juice. J. Bacteriology, 54, 697-708 (1947).

Misra, V., S. Solomon, M.I. Ansari, A.K. Shrivastava and A. Chandra: Leuconostoc bacterium: A cause for post-harvest sugarcane deterioration. Proc. of $3^{\text {rd }}$ LuSCON-2015 \& Nat. Conf. Sci. Soc. Interdisciplinary Approach, 122 (2015)

Misra, V., A.K. Mall, A.D. Pathak, S. Solomon and Ram Kishor: Microorganisms affecting post harvest sucrose losses in sugarcane. Int. J. Curr. Microbiol. App. Sci., 6, 2554-2566 (2017).

Misra, V., S. Solomon and M.I. Ansari: Impact of drought on post-harvest quality of sugarcane crop. Adv. Life Sci., 5, 9496-9505 (2016a).

Misra, V., S. Solomon, A.K. Shrivastava, S.P. Shukla and M.I. Ansari: Post harvest sugarcane deterioration: Leuconostoc and its effect. J. Funct. Environ. Bot., 6, 1-7 (2016)

Misra, V., S. Solomon, P. Singh, C.P. Prajapati and M.I. Ansari: Effect of water logging on post-harvest sugarcane deterioration. Agrica, 5, 119-132(2016b)

Nelson, N.: A photometric adaption of Somogyi method for determination of reducing sugar. J. Biol. Chem., 153, 375-380 (1944).

Philippe, R., A.R. Bailey, C.J. Comstock, J.B. Croft and A.S. Saumtall: A Guide to Sugarcane Diseases, Editions Quae, p. 339 (2000).

Sandhu, H.S., M.P. Singh, R.A. Gilbert and D.C. Odero: Sugarcane Botany: A Brief View. University of Florida. IFAS Extension, SSAGR-234, pp. 1-5 (2016).

Samina, M.: Microbes- Friends and foes of sugarcane. J. Basic Microbiol., 53, 954-971 (2012).

Sharma, A. and A. Chandra: Identification of new Leuconostoc species responsible for post-harvest sucrose losses in sugarcane. Sugar Tech, (2017). DOI 10.1007/s12355-017-0562-2.

Singh, I. and S. Solomon: Postharvest quality loss of sugarcane genotypes under sub tropical climate: Deterioration of whole stalk and billets. Sugar Tech., 5, 285-288 (2003)

Singh, R.K. and B.D. Chaudhury: Biometrical Methods in Quantitative Genetic Analysis. Kalyani Publishers, New Delhi, India (1985).

Singh, P., S. Solomon, C.P. Prajapati, S. Kumar, V. Misra and A. Chandra: Deterioration of fresh and stale cane juice at high ambient temperature in relation to expression of invertases and the growth of Leuconostoc spp. Agrica, 4, 79-85 (2015).

Solomon, S.: Post harvest cane deterioration and its milling consequences. Sugar Tech, 2, 1-18 (2000).

Solomon, S.: Post-harvest deterioration of sugarcane. Sugar Tech, 11, 109-123 (2009).

Suman, A., S. Solomon, D.V. Yadav, A. Gaur and M. Singh: Post harvest loss in sugarcane quality due to endophytic microorganisms. Sugar Tech, 2, 21-25(2000) 